\title{
DINAMIKA PEMIKIRAN NAHDLATUL ULAMA DALAM MERESPONS KEPEMIMPINAN NON MUSLIM DI INDONESIA
}

\author{
Izzul Madid \\ Universitas Ibrahimy Situbondo \\ JI. KHR. As'ad Samsul Arifin Sukorejo Situbondo \\ Email: izzulmadidra@gmail.com
}

\begin{abstract}
The leadership of non-Muslims in Indonesia had become a hot spotlight when the action 212 was held. Many people who later conducted a study of Islamic law about the validity of a non-Muslim was appointed as a leader. One study of this matter that is quite unique is the result of the Bahtsul Masail held by the GP Ansor which resulted in a conclusion that a non-Muslim is legitimately appointed as a leader in Indonesia. The results of this study reaped polemics because by some circles, it was considered to harm NU's thoughts which had been decided the 1999 Congress at Lirboyo. This article intends to explore how NU's real thinking as a Muslim mass organization is the largest in responding to nonMuslim leadership in the Indonesian context. From the results of this study, it was concluded that organizationally, NU had never discussed the issue of non-Muslim leadership specifically, either in the Congress or National Conference of Alim Ulama. The issue that has been raised by NU in relation to non-Muslim politics is around its electability as a legislative council.
\end{abstract}

Keywords: The Dynamics of Thought; Nahdlatul Ulama; Leadership; Non Muslim

Abstrak: Kepemimpinan non muslim di Indonesia sempat menjadi sorotan hangat tatkala aksi 212 digelar. Banyak kalangan yang kemudian melakukan kajian hukum Islam tentang keabsahan seorang non muslim diangkat sebagai pemimpin. Salah satu kajian tentang hal ini yang cukup unik adalah hasil Bahtsul Masail yang digelar oleh GP Ansor yang menghasilkan simpulan bahwa seorang non muslim sah-sah saja diangkat menjadi pemimpin di Indonesia. Hasil kajian ini menuai polemik karena oleh sebagian kalangan, dinilai menciderai pemikiran NU yang telah diputuskan pada Muktamar tahun 1999 di Lirboyo. Tulisan ini hendak mengupas bagaimana sebenarnya pemikiran NU sebagai sebuah organisasi massa Islam terbesar dalam merespon kepemimpinan non muslim untuk konteks Indonesia. Dari hasil kajian ini, diperoleh simpulan bahwa secara organisatoris, NU tidak pernah membahas isu tentang kepemimpinan non muslim secara khusus, baik dalam Muktamar atau Munas Alim Ulama. Isu yang pernah diangkat oleh NU terkait dengan politik non muslim adalah seputar keterpilihannya sebagai dewan legislatif.

Kata kunci: Dinamika Pemikiran; Nahdlatul Ulama; Kepemimpinan; Non Muslim.

\section{Pendahuluan}

Menurut Martin Van Bruinessen Nahdatul ulama merupakan salah satu organisasi massa terbesar yang unik, bukan hanya unik untuk tingkat nasional Indonesia, tetapi juga unik dalam kancah pemikiran Islam dunia. ${ }^{1}$ Sebagai sebuah organisasi muslim tradisionalis, tidak jarang dari tubuh NU muncul ide-ide yang

${ }^{1}$ Martin van Bruinessen, NU: Tradisi, Relasi-Relasi Kuasa, Pencarian Wacana Baru, ed. by Farid Wajidi, 5th edn (Yogyakarta: PT. LKiS, 2008). h. 1 tidak bisa disebut sebagai konservatif. Ia juga menghasilkan banyak cendikia yang sangat berpengaruh terhadap pemikiran Islam di Indonesia. ${ }^{2}$

NU sebagai organisasi massa yang menaungi sekitar 20 juta umat, memiliki sejarah panjang sejak kelahirannya pada 1926 hingga saat ini. Sejarah NU ini bisa dikelompokkan dalam

\footnotetext{
${ }^{2}$ Khoirun Niam, 'Nahdlatul Ulama and the Production of Muslim Intellectuals in the Beginning of 21St Century Indonesia', Journal of Indonesian Islam, 11.2 (2017), h. 351 <https://doi.org/10.15642/JIIS.2017.11.2.351-388>.
} 
5 periode. Pertama, NU sebagai organisasi keagamaan masyarakat (1926 - 1945). Kedua, NU yang bertarung dalam dunia politik praktis dengan ikut masuk pada partai Masyumi (1945 - 1952). Ketiga, NU sebagai partai mandiri setelah lepas dari masyumi (1952-1973). Keempat, NU kembali masuk dalam partai, yakni PPP (1973-1984). Kelima, NU kembali ke khittah sebagai organisasi non pemerintahan yang fokus pada keagamaan dan kemasyarakatan (1984 - sekarang). ${ }^{3}$

Periodesasi sejarah NU di atas mencerminkan betapa NU sangat dinamis dalam kehadirannya di tanah Indonesia. Dinamisasi ini tidak hanya dalam bentuk organisasi dan tujuannya, tetapi juga dalam ide-ide atau putusan-putusannya, NU mengalami perkembangan yang dinamis. Martin menyebutkan bahwa salah satu karakteristik NU adalah akomodatif terhadap perubahan-perubahan yang terjadi dalam kancah perpolitikan di Indonesia. ${ }^{4}$ Tidak hanya sebatas itu, NU juga akomodatif terhadap perubahan sosial dalam mengambil kebijakan, baik yang bersifat politik, keagamaan, keorganisasian, dan kemasyarakatan. $^{5}$

Dalam ranah politik, pemikiran dan kebijakan yang diambil NU sejak awal kehadirannya berkembang mengikuti gulir zaman. Saat masih dalam masa penjajahan, NU telah merumuskan tentang pentingnya nasionalisme. Bahkan, sebelum Indonesia merdeka, NU telah membicakaran tentang siapa yang berhak untuk menjadi presiden seandainya nanti merdeka dalam Muktamar ke-15 di Surabaya pada 1521 juli 1940. Berdasarkan rapat tertutup sebelas ulama pada saat itu, diputuskan Soekarno lah yang pantas menjadi presiden dibandingkan Hatta, padahal saat itu Soekarno dikenal sangat gandrung dengan pemikiran Kemal al-Taturk yang

${ }^{3}$ Faisal Ismail, 'THE NAHDLATUL ULAMA Its Early History and Contribution to the Establishment of Indonesian State', Journal of Indonesian Islam, 5.2 (2011) <https://doi. org/10.15642/JIIS.2011.5.2.247-282>. h. 247

${ }^{4}$ Martin van Bruinessen. h. 1

5 A Sunarto, 'Paradigma Nahdlatul 'ulama Terhadap Modernisasi’, Jurnal Sosiologi Islam, 3.2 (2013), h. 51-74. sekuler. Hal ini, menurut Tolhah, menunjukkan sikap NU yang lebih mengedepankan terjaganya perdamaian dan penilaian NU bahwa urusan politik dan negara bukan masuk pada ranah ushul al-din. ${ }^{6}$

Dengan dasar bahwa urusan politik dan negara bukan termasuk dalam ranah ushul al-din, maka pemikiran politik dan kenegaraan harus terus dikembangkan sesuai dengan situasi dan kondisi yang ikut menyertainya. Oleh sebab itu, pemikiran tentang kenegaraan dalam tubuh NU, selalu mengalami dinamika yang kadang kala terlihat tidak linear, sesuai dengan situasi yang sedang terjadi. Diskusidiskusi tentang bentuk negara, hubungan islam-negara, hingga hak-hak minoritas non muslim dalam politik kenegaraan, dibicarakan tidak hanya dalam level bawah, tetapi hingga level nasional dalam bentuk munas alim ulama dan muktamar. Pandangan dan pemikiran NU tentang hal-hal tersebut terus mengalami perkembangan seiring dengan perkembangan organisasi NU.

Dalam artikel ini, akan diulas tentang dinamika pemikiran NU mengenai politik kenengaraan dengan fokus yang lebih spesifik berupa kepemimpinan non muslim di Indonesia. Tidak hanya itu, tetapi juga tentang bagaimana produk pemikiran ini dihasilkan serta nilai signifikansinya pada masa produk pemikiran tersebut digulirkan.

\section{Kepemimpinan Non Muslim dalam Literatur Klasik}

Kepemimpinan non muslim dalam negara yang berasaskan agama (Islam), hampir disepakati ketidakbolehannya. Namun demikian, masih ada beberapa kalangan yang melegalkan seorang non muslim menjadi penguasa di negeri Islam. Polemik ini, awalnya muncul pada pemerintahan Umar bin Khattab saat melihat Abu Musa al-Asy'ari mengangkat sekretaris

${ }^{6}$ KH. Muhammad Tolhah Hasan, 'Nahdlatul Ulama Dan Negara Bangsa', in Majalah Aula, Pebruari (PWNU Jawa Timur: LTN PWNU Jatim, 1998). h. 63-65 
yang beragama Kristen. Sontak, Umar yang mengetahui hal itu, langsung memintanya untuk segera mengganti dengan orang lain yang muslim. ${ }^{7}$

Perdebatan Umar dan Abu Musa akhirnya melahirkan tiga kubu. Ada kubu yang tidak membolehkan non muslim untuk memiliki jabatan apapun. Ada kubu yang menyatakan keabsahan non muslim untuk menjadi pemimpin dalam jabatan apapun. Ada pula yang tidak membolehkan bila menjabat petinggi negara sekelas presiden, tetapi bila sebagai wazir/menteri yang kewenangannya adalah mematuhi presiden (khalifah), maka diperbolehkan.

Kubu pertama diwakili oleh Imam alJuwainiy, Ibn Jama'ah al-Hamawiy, Imam alAlusiy, Ibn al-Arabiy, Zamakhsyari, al-Syaukani, dan lainnya. ${ }^{8}$ Golongan kedua, oleh sebagian kalangan dinisbatkan kepada pendapat Ibn Taimiyah yang menyatakan bahwa lebih baik dipimpin oleh non muslim yang adil daripada dipimpin oleh muslim yang menyeleweng. ${ }^{9}$ Kalangan ketiga tercermin dari pendapat alMawardi non muslim bisa dipasrahi kedudukan setingkat menteri. Alasan al-Mawardiy, karena menteri saat itu hanya sebatas pelaksana titah khalifah. Ia tidak berhak membuat kebijakan. ${ }^{10}$ Senada dengan al-Mawardi adalah pendapat Abu Ya’la. Ia meriwayatkan dari al-Kharqiy bahwa non muslim bisa dipasrahi kedudukan sebagai menteri. Selain karena alasan yang disebutkan oleh al-Mawardiy, Abu Ya'la mengatakan bahwa posisi menteri hanyalah sebatas mediator antara khalifah dengan rakyatnya. Seandainya pun menteri punya pendapat lain, maka pendapatnya hanya dinilai sebagai saran, bukan kebijakan

\footnotetext{
${ }^{7}$ Al-Qurtuby, Al-Jami' Li Ahkam Al-Qur'an (Riyadh: Dar Alim al-Kotob, 2003). Jld. 4, h. 179

${ }^{8}$ Mary Silvita, 'Presiden Non-Muslim Dalam Komunitas Masyarakat Muslim', Islamica, 7.1 (2012). h. 46

${ }^{9}$ AT Khalik, 'Pemimpin Non-Muslim Dalam Perspektif Ibnu Taimiyah', ANALISIS: Jurnal Studi Keislaman, 14.1 (2015), h. 59-90 <https://ejournal.radenintan.ac.id/index.php/ analisis/article/view/609>.

${ }^{10}$ Al-Mawardi, Al-Ahkam Al-Sulthaniyah (Kuwait: Maktabah Dar Ibn Qutaibah, 1989). h. 27
}

karena dia tidak punya hak wilayah. ${ }^{11}$ Tidak hanya dari kalangan figh, para mufassir klasik juga hampir sepakat dengan ketidakbolehhan mengangkat non muslim sebagai pemimpin. Semua pendapat mufassir ini bertumpu pada ayat-ayat tentang wali ${ }^{12}$ yang diartikan sebagai pemimpin/penguasa. Sedangkan yang mengartikan wali sebagai teman dekat, hanyalah sebagian kecil mufassir. ${ }^{13}$

Bila ditakar, maka sebagian besar ulama klasik memilih pendapat bahwa non muslim tidak punya hak untuk jadi pimpinan dalam komunitas Islam. Hal ini tampaknya yang menjadi landasan Ibn Qayyim menyatakan telah terjadi konsensus di kalangan ulama tentang ketidakbolehan non muslim menjadi pemimpin.

Dari ranah kepemimpinan, akhirnya konsep muslim-non muslim ini juga merembet pada ranah publik dalam literatur kitab-kitab klasik yang dianggap mu'tabarah dalam NU. Bisa dilihat dari kitab Fath al-Wahhab, Fath al-Muin, al-Majmu', dan kitab otoritatif dalam mazhab syafi'i lainnya yang menegaskan bahwa umat non muslim merupakan masyarakat kelas kedua dalam negara islam dengan adanya kewajiban membayar jizyah. Mereka tidak hanya digerus hak-hak pribadinya, tetapi juga hak sosialnya dibatasi, termasuk dalam mengekspresikan ritual keagamaannya.

Konsep ulama klasik di atas, terlihat masih sangat normatif, rigid, dan intoleran. Dalam kajiannya, mereka kurang banyak-untuk mengatakan tidak-menyinggung aspek sosial, kultural, dan sejarah perpolitikan dalam komunitas muslim. Oleh karenanya, pendapat klasik di atas, terutama yang tidak membolehkan, kurang bisa diaplikasikan dalam komunitas muslim saat ini yang hidup dalam

\footnotetext{
${ }^{11}$ Kementerian Agama dan Wakaf, Al-Mausu'ah Al-Fighiyyah Al-Kuwaitiyah (Kuwait: Dar al-Salasil, 1404). Jld. 6, h. 148

${ }^{12}$ Misalnya ayat al-Maidah (5): 51

13 Kerwanto, 'Kepemimpinan Non-Muslim: Konsep Wilâyah Dalam Al-Qur' an Sebagai Basis Hukum', Kontemplasi, 5.2 (2017). h. 373
} 
situasi politik yang jauh berbeda. ${ }^{14}$ Terlebih bila dikontekstualisasikan dengan kehidupan Indonesia, dimana sejak awal, Indonesia bukanlah negara Islam. Melainkan negara yang kebetulan dipenuhi oleh pemeluk agama Islam. Bentuk negara ini tentu saja berpengaruh terhadap hak-hak politik yang diberikan pada warga negaranya. Yang menjadi agak sulit untuk dinilai adalah kondisi Indonesia yang masih 'abu-abu' antara negara sekuler dengan negara islam sehingga kebijakan hak politik warganya akan diarahkan ke mana, masih belum tegas. ${ }^{15}$ Namun, bila kita melihat pada landasan negara, akan terlihat bahwa Indonesia tergolong sebagai negara sekuler yang di dalamnya kontol agama melalui organisasi kemasyarakatan sangat kuat, terutama penetrasi NU terhadap kebijakan pemerintah.

Berbeda dengan ulama koontemporer yang sebagian besar telah mengakomodir kajian sosial, politik, ekonomi, dan sejarah dalam memahami ajaran-ajaran Islam. Mereka lebih terbuka untuk menerima non muslim sebagai pemimpin, seperti Mahmud Muhammad Thaha, Abdullah Ahmad Naim, Asghar Ali Enginer, Yusuf alQardhawiy dan Ali Jumuah. ${ }^{16}$ Bahkan, sebagian dari mereka ada yang tidak berlatar belakang syariah berpendapat bahwa kajian ulama klasik sudah selayaknya ditinggalkan sebab sudah out of date. ${ }^{17}$

\section{Proses Pengambilan Putusan dalam NU}

NU, yang merupakan akronim dari Nahdlatul Ulama, adalah organisasi yang dibentuk oleh para ulama. Secara harfiyah, ia bermakna kebangkitan ulama. Bila ditilik dari sejarah lahirnya, maka kehadiran NU tidak bisa dilepaskan dari tradisi pemikiran fiqh, baik fiqh sebagai produk siap pakai atau sebagai suatu

\footnotetext{
${ }^{14}$ M Ag H. Mujar Ibnu Syarif, 'Islamic Political Discourse on Non-Muslim Leadership in the Muslim State', Jurnal Syariah, 17.1 (2009), 223-42 <http://myais.fsktm.um.edu.my/9944/>. h. 223

${ }^{15}$ Mary Silvita. h. 44

16 Tariq Ramadan, Radical Reform: Islamis Ethics and Liberation (Oxford: Oxford University Press, 2009). h. 270

${ }^{17}$ H. Mujar Ibnu Syarif. h. 224
}

episteme (ushul fiqh dan qawaid fiqh). ${ }^{18}$

Pemikiran fikih dalam NU identik dengan fikih mazhab, dimana setiap persoalan keagamaan yang muncul, direspon dan dicari solusinya melalui forum bersama yang dikenal dengan Bahtsul Masail dengan tetap mengacu pada kitab-kitab fikih mu'tabarah dalam empat mazhab. Dengan tradisi pemikiran fikih empat mazhab ini, NU mencoba memberikan solusi terhadap tantangan perubahan yang dihadapi oleh masyarakat untuk melembagakan nilainilai baru serta tingkah laku dan peran sosiopolitiknya. ${ }^{19}$

Dalam organisasi NU, proses pengambilan keputusan tertinggi dilakukan pada pagelaran rutin yang dikenal dengan Musyawarah Alim Ulama. ${ }^{20}$ Musyawarah ini dihadiri oleh para tokoh NU dari seluruh cabang. Proses musyawarah ini, sangat didominasi oleh fikih sentris. Sejak tahun berdirinya hingga 1999, pembahasan fikih mendapatkan porsi $84,8 \%$ dari seluruh total pembahasan dalam Bahtsul Masail. ${ }^{21}$

Yang patut ditegaskan di sini adalah pembedaan antara Bahtsul Masail dengan Lajnah Bahtsul Masail (LBM). Bahtsul masail adalah proses pengambilan keputusan yang sudah dilakukan sejak 6 bulan setelah berdirinya NU 1926. Sementara LBM adalah institusi yang menyelenggarakan Bahstul Masail yang baru diusulkan pada Muktamar XXVIII di Jogja pada 1989 dan dilanjutkan pada Halaqah Denanya 1990. Akhirnya, pada tahun itu pula, LBM resmi dibentuk sebagai wadah pelaksana Bahtsul Masail. ${ }^{22}$

Proses perumusan jawaban dalam Bahtsul Masail, juga mengalami dinamika yang cukup bagus. Pada masa awal keberadaannya hingga

${ }^{18}$ M. Ali Haidar, Nahdalatul Ulama Dan Islam Di Indonesia: Pendekatan Figh Dalam Politik (Jakarta: PT. Gramedia Pustaka Utama, 1994). h. 8-9

${ }^{19}$ Ahmad Zahro, Tradisi Intelektual NU (Yogyakarta: LKiS, 2004). h. 2

${ }^{20}$ Martin van Bruinessen. h.192

${ }^{21}$ Zahro. h. 72

${ }^{22}$ Zahro. h. 68 
pada era 1980-an mulai ada geliat perubahan. Martin mencatat bahwa fatwa yang dihasilkan dari forum Bahtsul Masail sebelum era 1980an jarang bersifat inovatif; menolak ijtihad langsung dari al-Qur'an dan al-Hadits; lebih banyak mengacu pada kitab-kitab klasik secara langsung; dan memauqufkan persoalan yang tidak ditemukan teks tertulisnya pada kitabkitab tersebut. ${ }^{23}$

Walaupun pada masa-masa ini, Bahtsul Masail sangat kental dengan fikih Syafi'iyah nya, tidak jarang malah memilih pendapat yang bersebrangan dengan imam Syafi'iy yang didaulat sebagai mujtahid muthlaq. Hal ini terlihat saat keputusan muktamar NU ke-12 di Malang pada 25 Maret 1937 yang lebih memilih pendapat Imam Nawawi dari pada Imam Syafi'iy. ${ }^{24}$

Melihat realitas yang demikian, kalangan NU muda mulai merasa gelisah. Salah seorang diantara mereka berusaha memberikan perubahan pada Bahtsul Masail NU agar lebih akomodatif dan lebih bisa memberikan jawaban yang memuaskan kepada masyarakat. KH. Musthofa Bisri mengusulkan agar dalam forum Bahtsul Masail tidak hanya ditujukan untuk memberikan jawaban yang bersifat negasi atau afirmasi, tetapi juga harus menghadirkan dan melibatkan para ahli di bidang masingmasing untuk memperkaya sudut pandang terhadap masalah yang sedang dibahas. Selain itu, realita mauquf dalam Bahtsul masail juga harus dihindari. ${ }^{25}$ Pada masa tahun 1980-an inilah mulai digulirkan ide-ide pembaharuan. Pembaharuan bukan hanya dalam pola sidang, tetapi juga tema-tema yang diangkat bukan hanya tema 'desa', melainkan tema-tema 'nasional' ataupun regional.

Sejak Muktamar Situbondo 1984, isu-isu yang diangkat dalam Bahtsul Masail sudah mulai terasa agak berat. Dimulai dari penerimaan asas

\footnotetext{
${ }^{23}$ Martin van Bruinessen. h.193

24 Mujamil Qomar, NU Liberal: Dari Tradisionalisme Ahlussunnah Ke Universalisme Islam (Bandung: Mizan, 2002). h.72

${ }^{25}$ Martin van Bruinessen. h. 4
}

tunggal pancasila hingga urusan kenegaraan lainnya serta menyangkut urusan HAM dan Gender. Hal ini akibat penetrasi kaum muda NU yang dibacking oleh ketua umum saat itu, Gus Dur, dalam mengembangkan wacana pemikiran fikih di tubuh NU. ${ }^{26}$ Hingga pada awal 1990an, pemikiran fikih dalam NU mengalami pergumulan yang intensif dalam Bahtsul Masail. ${ }^{27}$ Akhirnya, pada Munas Alim Ulama 21-25 Januari 1992 di Lampung, diputuskan "Sistem Pengambilan Keputusan Hukum dalam Bahtsul Masail di lingkungan NU”. Dalam sistem ini, sudah dimasukkan proses istimbath, ilhaq, madzhab qauliy, dan manhajiy. Dengan adanya sistem ini, maka peran al-kutub al-mu'tabarah digeser. Al-kutub al-mu'tabarah yang awalnya adalah kitab-kitab fikih klasik dalam mazhab $4,{ }^{28}$ pada akhir 1980-an juga dimasukkan beberapa kitab lainnya yang ideologi dan alur pikirnya sama. Noer Iskandar bahkan mengatakan bahwa esensi bermazhab adalah mengikuti pendapat yang lebih memberikan mashlahah karena belum tentu pendapat klasik mazhab yang empat adalah yang benar. ${ }^{29}$

\section{Kelompok Konservatif - Progresif}

NU yang selama ini dianggap sebagai organisasi tradisional dengan basis pesantren, justeru memperlihatkan gairah progresifitas berpikir, dibandingkan dengan organisasi modern yang malah tampak stagnan dan resisten. ${ }^{30} \mathrm{Hal}$ ini terjadi pada dasawarsa 1980-an dan 1990an. Selain peristiwa penting pada muktamar Situbondo berupa kembalinya NU ke Khittah, juga adanya dinamika baru dalam tubuh NU

\footnotetext{
${ }^{26}$ Jamal Mảmur Asmawi, 'KEPEMIMPINAN PEREMPUAN : Pergulatan Wacana Di Nahdlatul Ulama (NU)', Addin, 9.1 (2015), h. 33-50.

${ }^{27}$ Ahmad Arif, 'DINAMIKA PEMIKIRAN FIQH DALAM NU (ANALISIS ATAS NALAR FIQH POLA MADZHAB)', Ulumuna Jurnal Studi Keislaman, XIII.1 (2009). h.190

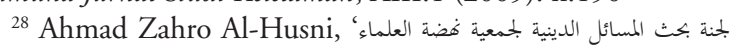
'بأندونيسيا: دراسة نقدية على المقررات الفقهية ', Journal of Indonesian Islam, 1.1 (2007), h. 212-22.

${ }^{29}$ KH. Noer Iskandar, 'Kedudukan Madzhab Dalam Islam: Studi Kasus Secara Umum Di NU', in Majalah Aula1, Pebruari (Surabaya: PWNU Jawa Timur, 1998). h. 68

${ }^{30}$ Sunarto. h. 57
} 
yang diwakili oleh generasi muda. Dinamika tersebut berupa menjamurnya aktifitas sosial dan intelektual yang nyaris tidak tertandingi oleh masyarakat atau organisasi lainnya. ${ }^{31}$

Aktifitas sosial dan intelektual makin mendapatkan tempat saat Gus Dur menjabat sebagai ketua umum. Tidak jarang tokoh muda ini sebenarnya adalah kepanjangan tangan ide-ide Gus Dur. Bila dicermati latar belakang para tokoh kaum progresif ini, tampak bahwa ada dua kecenderungan. Pertama, mereka yang berlatar belakang pendidikan pesantren dan melanjutkan ke jenjang pendidikan tinggi semisal IAIN. Dalam dunia akademik IAIN, mereka sudah mulai biasa dengan wacana kritis dan semangat modernisasi. Disamping itu, mereka juga kaya akan pengetahuan khazanah klasik pesantren sehingga mereka mampu mengetahui celah-celah yang harus diperbaiki atau dikritisi. Kedua adalah latar belakang pesantren yang dilanjutkan dengan pendidikan di Timur Tengah. Diantara mereka adalah KH. Sahal Mahfud, KH. Ach. Shiddiq, KH. Musthafa Bisri, KH. Said Aqil Sirajd dan lainlain. ${ }^{32}$

Keberadaan dua jenis kalangan muda NU di atas, membuat pergulatan pemikiran dalam tubuh NU menjadi tajam. Sebab, sudah sejak lama kalangan muda NU mengalami ketidakpuasan atas sikap generasi tua yang terlalu berorientasi pada pemikiran mazhab sehingga membentuk dan melestarikan status quo. Akhirnya terjadilah benturan antara kalangan yang menyarankan modernitas dalam berpikir dengan para generasi tua (kyai) yang konservatif. ${ }^{33}$

Setelah kemenangan kalangan muda NU dalam Muktamar Situbondo dengan Rois KH. Ach Shiddiq dan Ketua Gus Dur, kalangan muda mendapat akses yang cukup untuk meng-

\footnotetext{
${ }^{31}$ Martin Van Bruinessen, 'NU: Jama’ah Konservatif Yang Melahirkan Gerakan Progresif', in NU Muda: Kaum Progresif Dan Sekularisme Baru (Jakarta: Erlangga, 2004). viii

32 Laode Ida, NU Muda: Kaum Progresif Dan Sekularisme Baru (Jakarta: Erlangga, 2004). h.13

${ }^{33}$ Ahmad Arifi. h.198
}

ajak warga NU naik pada peringkat intelektual yang lebih tinggi dalam Bahtsul Masail. Isu-isu yang diangkat dalam era 1990-an sudah jauh melebihi pemikiran para kyai yang berasal dari kampung yang tidak mengenyam pendidikan kota. Misalnya tentang bayi tabung, KB, suntik mati, dll. Bahkan tidak jarang, NU menjadi opoisisi bagi pemerintah Orde Baru saat itu.

\section{NU dan Pemikiran Politik}

NU sebagai organisasi massa yang menaungi sekitar 20 juta umat, memiliki sejarah panjang sejak kelahirannya pada 1926 hingga saat ini. Sejarah NU ini bisa dikelompokkan dalam 5 periode. ${ }^{34}$ Pertama, NU sebagai organisasi keagamaan masyarakat (1926 - 1945). Pada masa ini, pemikiran NU banyak dicurahkan pada persoalan-persoalan keagamaan masyarakat yang sifatnya sederhana. Misalnya Muktamar Pertama pada tahun 1926 yang banyak membahas tentang bermazhab, kuburan, dan beberapa hal yang dianggap dapat melalaikan ibadah. ${ }^{35}$ Hal ini sebagai reaksi atas berdirinya NU yang menolak pembongkaran makam Rasulullah di Arab Saudi. Sehingga dirasa perlu untuk membahas hal-hal yang terkait dengan penguatan akidah umat dari paham Wahhabi yang anti klenik.

Kedua, NU yang bertarung dalam dunia politik praktis dengan ikut masuk pada partai Masyumi (1945 - 1952). Pada masa-masa ini, NU sepertinya belum sepenuh hati menjadi sebuah partai. Terbukti dengan tema-tema yang diangkat dalam Muktamar ke-16 tahun 1946, masih dalam bingkai nasionalisme. Isu-isu yang diangkat, antara lain tentang memerangi tentara musuh; zakat bagi sabilillah; perempuan ikut militer; syuhada; dan organisasi yang tidak berasaskan Islam. ${ }^{36}$

Ketiga, NU sebagai partai mandiri setelah

\footnotetext{
${ }^{34}$ Ismail. h.247 - 248

35 KH. A. Aziz Masyhuri, Masalah Keagamaan: Hasil Muktamar Dan Munas Alim Ulama Nahdlatul Ulama, 1st edn (Tanggerang: Qultum Media, 2004). h.1

${ }^{36}$ Masyhuri. h.161
} 
lepas dari masyumi (1952-1973). Sejak saat ini, pemikiran NU pun tersita dengan masalahmasalah kepartaian sehingga dinamika pemikiran dalam tubuh NU kurang tumbuh. ${ }^{37} \mathrm{Hal}$ ini terlihat dari isu yang diankat pada Muktamar ke-20 pada 1954 yang hanya mengangkat 5 masalah. Salah satu diantaranya adalah penyematan status waliyyul amri al-dharuriy bi alsyaukah kepada presiden Soekarno. Pada tahuntahun ini, isu politik banyak masuk dalam diskusi-diskusi NU. Pada tahun 1957, Konbes NU membahas tentang kemungkinan wanita menjadi anggota DPR/DPRD yang kemudian diputuskan kebolehannya. ${ }^{38}$

Pada tahun 1961, keputusan Rapat NU hanya memutuskan 1 persoalan, yakni tentang kepemimpinan perempuan sebagai kepala desa. ${ }^{39}$ Ada yang menarik dalam putusan ini. Bila model putusan-putusan sebelumnya hanya mencukupkan pada jawaban iya atau tidak, maka pada keputusan ini, terkesan NU berusaha memberikan celah. Dalam putusannya dikatakan bahwa sebenarnya wanita tidak diperkenankan untuk menjadi pemimpin dalam 3 mazhab utama, Syafi'iy, Maliki, dan Hanbali. Tetapi, NU malah memilih pendapat Hanafi yang diperkuat oleh Ibn Jarir. ${ }^{40}$

Tidak pernah dalam putusan-putusan sebelumnya, NU berusaha menjelaskan secara detail hingga pada perbedaan pendapat yang agak beragam. Tampak jelas bahwa faktor politik sangat berpengaruh saat NU menjadi partai tersendiri.

Keempat, NU kembali masuk dalam partai, yakni PPP (1973-1984). Pada masa ini, tidak ada pembahasan yang terkait dengan politik dalam muktamar atau munas alim ulama NU. Yang cukup fenomenal pada periode ini adalah kembalinya NU ke Khittah pada tahun 1984 sebagai tanda perubahan yang signifikan dalam tubuh organisasi dan pemikiran NU.

\footnotetext{
${ }^{37}$ Niam. h.383

${ }^{38}$ Masyhuri. h. 173

${ }^{39}$ Masyhuri. h. 198

${ }^{40}$ Masyhuri. h.199
}

Kelima, NU kembali ke khittah sebagai organisasi non pemerintahan yang fokus pada keagamaan dan kemasyarakatan (1984sekarang). Sejak tahun-tahun ini, produk pemikiran resmi NU lebih banyak difokuskan pada persoalan-persoalan riil masyarakat. Hingga pada tahun 1990-an, isu-isu kepemimpinan kembali menyeruak, terutama pada tahun 1997-2000. Akan tetapi, isu-isu ini tidak dibahas dalam Munas dan Muktamar kecuali tentang isu wanita berpolitik (1997) dan non muslim sebagai anggota DPR (1999). ${ }^{41}$

Isu-isu politik banyak dibicarakan di luar forum tertinggi NU. Banyak artikel tentang pemikiran pribadi tokoh-tokoh NU yang diterbitkan majalah Aula pada masa 1997 2000 yang menyorot persoalan demokrasi. Misalnya, Said Aqil Siradj: Konsep Imamah dalam Perspektif Demokrasi; ${ }^{42}$ Noer Iskandar: Politik Islam di Indonesia Peran Ulama dan Umat Islam; ${ }^{43}$ Idrus Ramli: Islam dan Posisi Politik; ${ }^{44}$ Said Aqil Siradj: Presiden Wanita; ${ }^{45}$ Muhammad Tolhah Hasan: NU dan Negara Bangsa; ${ }^{46}$ Hasjim Abbas: Wanita Boleh Jadi Presiden. ${ }^{47}$

\section{Kepemimpinan Non Muslim}

Sejak adanya kasus pengutipan surat alMaidah ayat 51 oleh Ahok di Kepulauan Seribu, isu tentang kepemimpinan non muslim kembali menyeruak. Terlepas dari apa motif di balik kasus itu, dalam tulisan ini hanya akan menelisik tentang pemikiran NU mengenai kepemimpinan non muslim.

${ }^{41}$ Masyhuri. Jld. h. 2

${ }^{42}$ Said Aqil Siradj, 'Konsep Imamah Dalam Perspektif Demokrasi', in Majalah Aula, 1999. h.71-77

${ }^{43} \mathrm{KH}$. Noer Iskandar, 'Politik Islam Di Indonesi: Peran Ulama Dan Umat Islam', in Majalah Aula, Pebruari (Surabaya: PWNU Jawa Timur, 1998). h.62-67

${ }^{44}$ M. Idrus Romli, 'Islam Dan Posisi Politik', in Majalah Aula, Pebruari (Surabaya: PWNU Jawa Timur, 1999). h.81

${ }^{45}$ Said Aqil Siradj, 'Presiden Wanita', in Majalah Aula, Nopember (Surabaya: PWNU Jawa Timur, 1998). h.44-46

${ }^{46}$ Hasan. h.61-70

${ }^{47}$ Hasjim Abbas, 'Wanita Boleh Menjadi Presiden', in Majalah Aula, Januari (Surabaya: PWNU Jawa Timur, 1999). h. $81-90$ 
NU, melalui Muktamar, Munas dan Konbes nya, sangat jarang mengangkat isu-isu politik dalam bahtsul masail diniyah. NU lebih banyak memberikan saran-saran atau rekomendasi kepada pemerintah terkait penyelenggaraan tugastugasnya. Misalnya Konbes pada tahun 1997 yang menghasilkan beberapa rekomendasi kepada pemerintah untuk melanjutkan pembangunan dan membenahi beberapa hal. ${ }^{48}$

Isu kepemimpinan yang dibahas dalam Bahtsul Masail hanya tentang kepemimpinan perempuan. Sementara isu kepemimpinan yang terkait dengan non muslim yang tercatat hanya terjadi pada Muktamar 1999 di Lirboyo dan Bahtsul Masail Kyai Muda Ansor.

Yang dipersoalkan pada Muktamar Lirboyo, salah satunya adalah tentang hukum umat muslim memilih anggota legislatif (MPRDPR) non muslim. Dalam penjelasannya, umat muslim tidak diperbolehkan menguasakan urusan kenegaraan Indonesia kepada non muslim kecuali dalam kondisi darurat sebagai berikut: ${ }^{49}$

1. Dalam bidang-bidang yang tidak ditangani oleh orang islam sendiri secara langsung atau tidak langsung karena faktor kemampuan.

2. Dalam bidang-bidang yang ada orang islam berkemampuan untuk menangani tetapi terdapat indikasi kuat bahwa yang bersangkutan khianat.

3. Sepanjang penguasaan kepada non muslim itu nyata membawa manfaat.

Selain memberikan kriteria kondisi seperti di atas, putusannya juga diberi catatan bahwa yang dimaksud oleh non muslim adalah ahl al-dzimmah dan harus ada mekanisme kontrol yang efektif.

Dari putusan itu, tampaknya NU masih belum terlihat sebagai organisasi yang ramah terhadap minoritas. Terlebih masih menggunakan terma ahl al-dzimmah yang memiliki landasan cukup kuat dalam khazanah fikih klasik sebagai

\footnotetext{
${ }^{48}$ Majalah Aula, Januari 1998, h. 86

${ }^{49}$ Masyhuri. Jld. 2, h.157-158
}

masyarakat kelas dua. Penggunaan terma ini sangat tidak kontekstual bila dilandingkan di Indonesia. Sebab, indonesia bukanlah negara Islam yang mengharuskan umat non muslim membayar jizyah. Konsep ahl al-dzimmah hanya berlaku—sebagaimana dalam fikih klasik—dalam negara Islam, yakni negara yang melandaskan asas negaranya pada agama Islam.

Pandangan NU secara organisasi masih belum beranjak dari fikih sentries. Walaupun dalam putusan di atas, ada rujukan berupa ayat al-Qur'an, tetapi ayat itu hanya sebagai pajangan saja. Rujukan-rujukan yang malah dijadikan sandaran tetaplah kitab-kitab mu'tabarah klasik semisal al-Tuhfah karya Ibn Hajar al-Haytami, al-Syarwani yang merupakan komentar terhadap al-Tuhfah, dan alMahally yang merupakan kitab komentar terhadap al-Minhaj kemudian al-Ahkam alSulthaniyah karya al-Mawardi.

Kitab-kitab tersebut dikutip begitu saja tanpa ada kontekstualisasi dengan dunia keindonesiaan. Jauh berbeda saat membahas kepemimpinan perempuan sebagai kepala desa pada tahun 1961.

Sementara hasil bahtsul masail kyai muda Ansor pada Maret 2017 memutuskan bahwa non muslim berhak untuk menjadi pemimpin. Dalam surat putusannya, GP Ansor menjelaskan secara panjang lebar tentang kemungkinan non muslim untuk menjadi pemimpin. Mereka tetap melirik kepada keputusan Muktamar sebelumnya; 1936 tentang status negara Indonesia, 1954 tentang status presiden Soekarno; dan 1999 tentang Anggota Legislatif non Muslim. Ketiga muktamar ini, oleh GP Ansor, menjadi argumen penting betapa pemikiran NU tentang kepemimpinan sangat dinamis. ${ }^{50}$

Untuk sampai pada simpulannya, GP Ansor banyak mengurai tentang aspek sosial, kultural, dan politik yang jauh berbeda dengan masa-masa ketika kitab-kitab rujukan dalam 3 muktamar itu dikarang. Selain itu, GP

\footnotetext{
${ }^{50}$ Pimpinan Pusat GP Ansor, Keputusan Bahtsul Masail Kyai Muda Ansor (Jakarta, 2017).
} 
Ansor juga mencatut beberapa pemikir Islam Kontemporer untuk menguatkan simpulannya, semisal Ali Jum'ah.

Keputusan GP Ansor, oleh beberapa kalangan, dinilai sebagai telah menyalahi keputusan Muktamar Lirboyo 1999. Makruf Amin misalnya, mengatakan bahwa keputusan Muktamar tidak bisa dibatalkan oleh Bahtsul Masail. Muktamar adalah forum tertinggi dalam NU dan hasil putusannya hanya bisa dibatalkan oleh Muktamar berikutnya. ${ }^{51}$ Demikian pula keputusan Bahtsul Masail, tidak boleh bertentangan dengan Muktamar. Bahkan ada juga kalangan yang menganggap bahwa pemberian fatwa hukum bukan ranah GP Ansor. Itu adalah ranah Lembaga Bathsul Masail. ${ }^{52}$

Selain dalam forum-forum resmi, para tokoh NU juga banyak berbicara tentang politik. Bahkan, intensitas kajian mereka tentang kepemimpinan non muslim lebih banyak dilakukan di luar forum Muktamar dan Munas Alim Ulama. Diantara tokoh-tokoh tersebut adalah Gus Dur, Said Aqil Siradj, Tolhah Hasan, Dawam Raharjo, dan Ali Yafi. Dalam tubuh NU, para tokohnya terpecah menjadi tiga kecenderungan dalam mengomentari kepemimpinan non muslim di Indonesia. Pertama adalah KH. Ali Yafi yang menyatakan bahwa non muslim di Indonesia adalah dzimmiy sehingga mereka punya beban untuk membayar jizyah pada pemerintah. Hanya saja, Ali Yafi tetap tidak setuju bila warna non muslim didiskriminasi dalam bidang-bidang sosial dan politik. Menurutnya, non muslim punya hak yang sama dengan umat islam dalam kancah perpolitikan, selain sebagai kepala negara. Karena itu, non muslim masih punya hak untuk menjabat sebagai menteri..$^{53}$ Pemikiran Ali Yafi ini sangat

\footnotetext{
51 https://www.tribunislam.com/2017/03/soal-gp-ansor-raisaam-pbnu-bahtsul-masail-tidak-boleh-bertentangan-denganmuktamar.html

52 http://www.muslimoderat.net/2017/03/meluruskan-kabarbahtsul-masail-gp-ansor-menyalahi-muktamar-lirboyo.html

53 Masykuri Abdillah, Demokrasi Di Persimpangan Makna (Yogyakarta: Tiara Wacana, 1999). h. 119
}

selaras dengan pandangan al-Mawardi dan Abu Ya'la. Tampaknya, pemikiran al-Mawardi inilah yang banyak dijadikan landasan oleh para kyai di NU dalam memberikan pandangan seputar fikih perpolitikan.

Menanggapi hal ini, Tolhah Hasan menyatakan bahwa pemikiran tentang negara bangsa dalam tubuh NU, walaupun didukung, terbentur dengan kendala-kendala fiqhiyah. Di antaranya adalah kitab-kitab fikih siyasah yang digunakan ditulis pada abad $3-5 \mathrm{H}$ yang tentu saja kondisi perpolitikannya jauh berbeda dengan konteks Indonesia saat ini. Di samping itu, kajian-kajian fikih siyasah tidak banyak mengalami perkembangan yang berarti. Tolhah menyarankan agat ada sikap reformatif melihat wacana-wacana kenegaraan saat ini dalam rangka merespon perkembangan zaman. Dia mengusulkan, diantaranya, memperluas konsep fiqh al-musawah hingga bisa mencakup pada hak-hak perempuan dan non muslim dalam ranah publik dan politik. ${ }^{54}$

Tampaknya, kegusaran yang dialami Tolhah cukup berasalan bila melihat pendapat Ali Yafi sebagaimana di atas. Ali Yafi adalah salah satu tokoh NU yang mencerminkan kalangan tua yang corak pemikirannya sangat mendominasi warga NU. Terlihat bagaimana pandangan Ali Yafi masih didasarkan pada al-ahkam alsulthaniyah karya al-Mawardi yang dikarang pada abad ke-5 dengan situasi politik dinasti (teokrasi).

Kedua, golongan Gus Dur, Said Aqil Sirajd. Gus Dur mengatakan bahwa non muslim yang ada di Indonesia tidak bisa disebut sebagai dzimmy sebab Indonesia bukanlah negara Islam, melainkan negara yang berdasarkan pada UUD 45. Oleh sebab itu, setiap warga negara memiliki derajat dan hak yang sama di hadapan hukum, tidak ada masyarakat kelas kedua walaupun sebagai minoritas. Dengan adanya hak yang sama ini, maka warga negara non muslim pun berhak untuk memilih dan dipilih sebagai kepala negara sebagaimana

${ }^{54}$ Hasan. h.66-69 
warga muslim. Gus Dur lebih banyak mendasari pendapatnya dengan menyitir UndangUndang yang memungkinkan non muslim menjadi pemimpin. Tetapi ia juga tidak menafikan hak umat muslim untuk memilih pemimpin yang seagama. ${ }^{55}$

Hampir senada dengan Gus Dur, Said Aqil Siradj juga berkesimpulan bahwa non muslim punya hak yang sama di Indonesia untuk diangkat menjadi kepala negara. ${ }^{56}$ Ia mendasari argumennya dengan teori imamah yang menurutnya bukan bagian dari ushul al-din. Karena itu, konsep dan penerapan imamah yang ada dalam beragam kitab fikih masih terbuka untuk interpretasi yang harus disesuaikan dengan kondisi riil masyarakat modern saat ini. Seringkali ia menyitir perkataan Ibn Taimiyah yang mengindikasikan bahwa pemimpin non muslim yang adil lebih baik daripada pemimpin muslim yang zalim. ${ }^{57}$

Kelompok ketiga adalah Dawam Raharjo. Menurutnya, konsep dzimmiy sudah tidak bisa diberlakukan untuk saat ini. Sebab, konsep tersebut hadir pada masa peperangan antara umat Islam dengan Kristen sehingga ada pembagian kafir harbiy, dzimmiy, mu'ahad. Secara tegas Raharjo mengatakan bahwa non muslim punya hak-hak yang sama dengan umat islam, termasuk hak untuk menjadi pemimpin. Hanya saja, umat Islam, secara moral terikat pada aturan untuk tidak memilihnya. ${ }^{58}$ Dari sini tampak bahwa Raharjo menggunakan dua kacamata dalam menilai kepemimpinan non muslim di Indonesia. Pertama, dia menggunakan pendekatan nation-state yang bukan lagi negera agama sehingga tiap warga negara punya hak yang sama. Kedua, sebagai muslim, tidak bisa dipersalahkan bila menentukan pilihannya dengan berlandaskan pada agama dalam negara yang demokrasi.

\footnotetext{
${ }^{55}$ Abdillah. h.122

${ }^{56}$ Qomar. h.197

57 Siradj, 'Konsep Imamah Dalam Perspektif Demokrasi'. h.71-77

${ }^{58}$ Abdillah. h.123
}

\section{Penutup}

Dari berbagai penjelasan di atas, dapat disimpulkan bahwa secara organisatoris, NU tidak pernah membahas isu tentang kepemimpinan non muslim secara khusus, baik dalam Muktamar atau Munas Alim Ulama. Isu yang pernah diangkat oleh NU terkait dengan politik non muslim adalah seputar keterpilihannya sebagai dewan legislatif. Dalam hal ini, NU memberikan pandangan yang sangat normatif bahwa umat muslim tidak boleh menguasakan urusannya kepada non muslim kecuali dalam kondisi darurat, termasuk di dalamnya penguasaan sebagai wakil rakyat. Dari tanggapan yang normatif ini, kemudian tetap dipegang teguh dan diperluas maknanya kepada penguasaan sebagai presiden. Namun, kalangan muda NU semisal Ansor, memberikan interpretasi berbeda terhadap rumusan NU 1999 tersebut.

Selain pendapat kelembagaan, banyak tokohtokoh NU secara individual yang masuk dalam golongan progresif, menyuarakan kesamaan hak antara muslim dan non muslim, termasuk hak konstitusional memilih atau dipilih untuk jabatan apapun yang diantaranya adalah presiden. Hanya saja, suara-suara individu ini tidak bisa dijadikan ketetapan yang dapat dinilai sebagai suara organisasi NU karena belum diputuskan dalam Munas atau Muktamar manapun. Namun, tokoh-tokoh tersebut cukup representatif bagi kalangan elit NU, tidak bagi kalangan NU kultural yang sebagian besar masih konservatif.

\section{Pustaka Acuan}

Abbas, Hasjim. 'Wanita Boleh Menjadi Presiden', in Majalah Aula, Januari, Surabaya: PWNU Jawa Timur, 1999

Abdillah, Masykuri. Demokrasi Di Persimpangan Makna,Yogyakarta: Tiara Wacana, 1999

Ahmad, Arifi. 'Dinamika Pemikiran Fiqh Dalam $\mathrm{Nu}$ (Analisis Atas Nalar Fiqh Pola Madzhab)', Ulumuna Jurnal Studi Keislaman, XIII (2009) 
Al-Husni, Ahmad Zahro. 'لجنة بحث المسائل الدينية لمجعية غضة العلماء بأندونيسيا: دراسة نقدية على الماتلى المقررات الفنهية', Journal of Indonesian Islam, 1 (2007), 212-22.

Al-Mawardi, Al-Ahkam Al-Sulthaniyah (Kuwait: Maktabah Dar Ibn Qutaibah, 1989)

Al-Qurtuby, Al-Jami' Li Ahkam Al-Qur'an, Riyadh: Dar Alim al-Kotob, 2003

Ansor, Pimpinan Pusat GP, Keputusan Bahtsul Masail Kyai Muda Ansor Jakarta, 2017

Asmawi, Jamal Ma'mur. 'Kepemimpinan Perempuan : Pergulatan Wacana Di Nahdlatul Ulama ( NU )', Addin, Vol. 9, 2015.

Bruinessen, Martin van. NU: Tradisi, RelasiRelasi Kuasa, Pencarian Wacana Baru, ed. by Farid Wajidi, 5th edn, Yogyakarta: PT. LKiS, 2008.

Bruinessen, Martin Van. 'NU: Jama'ah Konservatif Yang Melahirkan Gerakan Progresif', in NU Muda: Kaum Progresif Dan Sekularisme Baru, Jakarta: Erlangga, 2004.

Mujar Ibnu Syarif, 'Islamic Political Discourse on Non-Muslim Leadership in the Muslim State', Jurnal Syariah, Vol. 17, 2009, <http:// myais.fsktm.um.edu.my/9944/>

Haidar, M. Ali. Nahdalatul Ulama Dan Islam Di Indonesia: Pendekatan Fiqh Dalam Politik (Jakarta: PT. Gramedia Pustaka Utama, 1994)

Hasan, KH. Muhammad Tolhah. 'Nahdlatul Ulama Dan Negara Bangsa', in Majalah Aula, Pebruari, PWNU Jawa Timur: LTN PWNU Jatim, 1998.

Ida, Laode. NU Muda: Kaum Progresif Dan Sekularisme Baru, Jakarta: Erlangga, 2004.

Iskandar,. Noer. 'Kedudukan Madzhab Dalam Islam: Studi Kasus Secara Umum Di NU', in Majalah Aula1, Pebruari, Surabaya: PWNU Jawa Timur, 1998.

, 'Politik Islam Di Indonesi: Peran Ulama Dan Umat Islam', in Majalah Aula, Pebruari, Surabaya: PWNU Jawa Timur, 1998.
Ismail, Faisal. 'The Nahdlatul Ulama Its Early History and Contribution to the Establishment of Indonesian State', Journal of Indonesian Islam, Vol. 5, 2011 <https:// doi.org/10.15642/JIIS.2011.5.2.247-282>

Kerwanto, 'Kepemimpinan Non-Muslim : Konsep Wilâyah Dalam Al-Qur'an Sebagai Basis Hukum', Kontemplasi, Vol. 5, 2017.

Khalik, AT, 'Pemimpin Non-Muslim Dalam Perspektif Ibnu Taimiyah', ANALISIS: Jurnal Studi Keislaman, Vol. 14, 2015, $<$ https://ejournal.radenintan.ac.id/index. php/analisis/article/view/609>

Mary, Silvita. 'Presiden Non-Muslim Dalam Komunitas Masyarakat Muslim', Islamica, Vol. 7, 2012.

Masyhuri, A. Aziz. Masalah Keagamaan: Hasil Muktamar Dan Munas Alim Ulama Nahdlatul Ulama, 1st edn, Tanggerang: Qultum Media, 2004.

Niam, Khoirun. 'Nahdlatul Ulama and the Production of Muslim Intellectuals in the Beginning of 21StCentury Indonesia', Journal of Indonesian Islam, Vol. 11, 2017, <https:// doi.org/10.15642/JIIS.2017.11.2.351-388>

Qomar, Mujamil. NU Liberal: Dari Tradisionalisme Ahlussunnah Ke Universalisme Islam, Bandung: Mizan, 2002.

Ramadan, Tariq. Radical Reform: Islamis Ethics and Liberation, Oxford: Oxford University Press, 2009.

Romli, M. Idrus. 'Islam Dan Posisi Politik', in Majalah Aula, Pebruari, Surabaya: PWNU Jawa Timur, 1999.

Siradj, Said Aqil. 'Konsep Imamah Dalam Perspektif Demokrasi', in Majalah Aula, 1999

, 'Presiden Wanita', in Majalah Aula, Nopember, Surabaya: PWNU Jawa Timur, 1998.

Sunarto, A, 'Paradigma Nahdlatul 'ulama Terhadap Modernisasi', Jurnal Sosiologi Islam, Vol. 3, 2013. 
Wakaf, Kementerian Agama dan, Al-Mausu'ah Al-Fiqhiyyah Al-Kuwaitiyah, Kuwait: Dar al-Salasil, 1404.
Zahro, Ahmad. Tradisi Intelektual NU, Yogyakarta: LKiS, 2004. 